\title{
Patent ruling could cut PCR enzyme prices
}

Rex Dalton, San Diego

The European Patent Office (EPO) last week revoked a patent for an important thermally stable enzyme used in the polymerase chain reaction (PCR) process for DNA amplification. The decision brings with it the prospect that the price of the enzyme will fall.

Hoffmann-La Roche's patent for naturally occurring Taq DNA polymerase obtained from the bacterium Thermus aquaticus, which lives in hot springs - is invalid because it is not a novel invention and is based on previously published discoveries, EPO officials say. Roche says it will appeal against the decision next year once the formal written opinion is issued by the EPO in Munich.

Melinda Griffith, general counsel for Roche Molecular Systems in Pleasanton, California, downplayed what she called "an intermediate-level" decision. She said the panel of patent examiners responsible had made "many errors of law" during the threeday hearing, which ended on 30 May.

This is the second major Roche patent on PCR to be revoked. In 1999, a federal judge in San Francisco ruled that Roche's US patent for native Taq was invalid (see Nature 402, 709 ; 1999) because it had been obtained with "intent to mislead". Switzerland-based

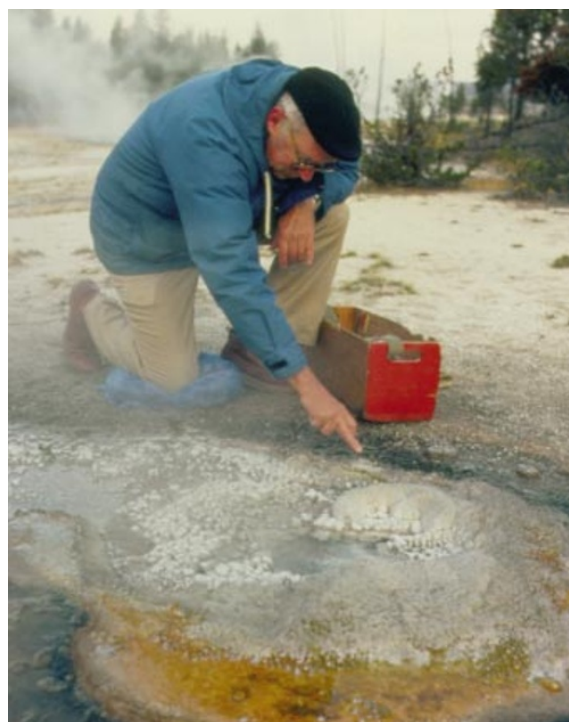

Getting warmer: Tom Brock of the University of Wisconsin, who discovered Thermus aquaticus.

Roche is appealing against that decision, and a court ruling is expected next year.

In both the EPO and San Francisco cases, the Roche patents were disputed by Promega, a Wisconsin-based company that markets native Taq and other reagents internationally. Three other companies -
Bioline, New England Biolabs and Becton Dickinson - supported Promega in the EPO action. The companies argued that the EPO patent for native Taq, issued in 1997, should never have been allowed and was granted only after years of pressure by Roche and its subsidiaries.

Roche still holds an EPO patent for a recombinant version of Taq, which is created by inserting the gene for Taq into another species of bacterium. Recombinant Taq now accounts for a large proportion of the market. But that patent is being challenged by the London-based company Bioline.

Bioline declined to comment on the case. But Griffith claims Roche's EPO patent on recombinant Taq is valid and enforceable.

In a separate action, Roche is suing Promega in the German federal court for selling Taq in Europe, alleging that the company is infringing its patents. It remains unclear how the EPO will ruling will affect this action.

Promega lawyer Brenda Furlow claims that more companies are now likely to start selling native Taq, creating a more competitive market that will lower the price of the widely used reagent. Native Taq produced by the companies fighting Roche costs $20-30 \%$ less than Roche charges, she notes.

\section{French unions walk out of talks over 35-hour week}

\section{Sally Goodman, Paris}

Unions representing French researchers walked out of a meeting at the Ministry of Research last week in protest at the government's plans to introduce a 35 -hour week. The dispute centres on the government's refusal to create new positions to compensate for the working time lost.

"Any measure to reduce working hours should be accompanied by new posts, otherwise our research potential will

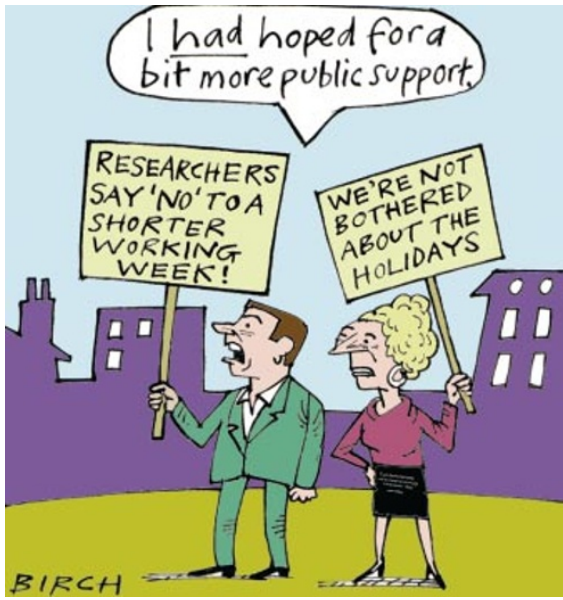

decrease," warns Jacques Fossey, secretary general of the scientific researchers' trade union SNCS-FCU. The unions will decide what action to take after a further meeting with government officials on 26 June. Other public-sector unions have called strikes.

Fossey estimates that most researchers work between 45 and 50 hours a week on 39hour contracts. "For researchers, working a 35-hour week has no real meaning," he says.

The French public research agencies, such as the CNRS (the national agency for basic research), are being asked to implement a new law by January 2002 which stipulates that all civil servants should work a 35-hour week, or a maximum of 1,600 hours per year, with extra hours being compensated by additional days off. The legislation will also cover university staff.

"We think the research agencies are being offered a good deal," says a ministry spokeswoman. "Staff will be able to save up their extra days off over five years and take extended holidays, and there will also be financial compensation." She adds that new posts are budgeted for in 2002, although these are not directly linked to the new law.

Abderrahmane Tadjeddine, director of the LURE synchrotron laboratory in Orsay, near Paris, says that the main problem is implementing a system that will keep machines operating round the clock.

In the private sector, the 35-hour week has established itself firmly as part of French culture since its introduction over a year ago. Many observers say that it has fulfilled the government's stated objective of creating new jobs. A recent government survey found that $59 \%$ of those affected say their lives have improved.

But applying the law to civil servants, of which there are nearly 5 million in France, is proving problematic. The government is standing firm on its decision that no new jobs will be created in the public sector to compensate for the reduction in hours.

The situation is complicated by the fact that research agencies such as the Atomic Energy Commission (CEA) and the French national space agency (CNES) have industrial rather than civil-service status and so have already introduced the shorter working hours. The CEA has announced that 500 new posts will be created over three years, but this has been achieved only after difficult negotiations and a salary freeze. 